\title{
Kezdeti tapasztalataink öntáguló flexibilis sztenttel az arteria poplitea atheroscleroticus betegségeinek kezelésében
}

\author{
Takács Tibor dr. - Mihalovits Gábor dr. \\ Váradi Rita dr. - Palásthy Zsolt dr. \\ Szegedi Tudományegyetem, Általános Orvostudományi Kar, Szent-Györgyi Albert Klinikai Központ, \\ Sebészeti Klinika, Szeged
}

\begin{abstract}
Bevezetés: Napjainkban a perifériás verőérbetegségek incidenciája mellett a sürgős végtagmentő mútétet igénylő, kritikus végtagischaemiás esetek aránya is növekszik. A modern orvoslás alapelve a minimálinvazivitás szemlélete, így az érrendszer helyreállító beavatkozásaiban is elsődlegessé váltak az endovascularis technikák. Az arteria poplitea atheroscleroticus betegségei korábban a térd alá vezetett femoropoplitealis bypassmútét indikációját jelentették. Manapság egyre gyakrabban használunk intervenciós megoldásokat, ezen az érszakaszon azonban a sztentek használatának indikációjában az irodalom nem egységes.

Célkitüzés: Érsebészeti osztályunkon 2016. január óta használunk Jaguár öntáguló flexibilis sztenteket az arteria poplitea atheroscleroticus betegségeinek kezelésére, célunk ezen beavatkozások effektivitásának vizsgálata volt.

Módszer: Vizsgálatunkba klinikánk Érsebészeti Osztályán 2016. január 1. és 2017. december 31. között olyan arteria poplitea intervención átesett betegeket válogattuk be, akiknél Jaguár sztent beültetése is történt. Egyéves utánkövetés során vizsgáltuk a sztentek átjárhatóságát, az amputációmentes túlélést és az ezeket befolyásoló rizikófaktorokat.

Statisztikai analizis: A folyamatos változók összehasonlítását Student-féle t-teszttel, a kategorikusokat khi-négyzetpróbával végeztük.

Eredmények: A vizsgált időszakban 33 esetben végeztünk olyan poplitea, illetve femoropoplitealis endovascularis beavatkozást, melynek során az arteria poplitea szegmentbe Jaguár sztent beültetése is történt. Reoperációt igénylő posztintervenciós szövődmény 2 esetben fordult elő. Az utánkövetés során az első év végén a popliteasztentek primer átjárhatósága 58,1\%-os, szekunder átjárhatósága 74,2\%-os, míg az amputációmentes túlélés 96,8\%-os volt.

Következtetés: Eredményeink alapján - a nemzetközi irodalmi adatokkal összehasonlítva - megállapítható, hogy bár a Jaguár sztentek egyéves primer átjárhatósága relatíve alacsonyabb, az egyéves amputációmentes túlélés már jónak mondható, emellett a módszer sok esetben lényegesen kisebb mútéti terheléssel jár.
\end{abstract}

Orv Hetil. 2020; 161(15): 588-593.

Kulcsszavak: kritikus végtagischaemia, endovascularis technika, öntáguló sztent

\section{Early experience with self-expanding flexible stent for the treatment of atherosclerotic diseases in the popliteal artery}

Introduction: The incidence of peripheral arterial diseases and the rate of chronic limb-threatening ischaemia are increasing year by year. Minimally invasive peripheral interventions have gradually replaced traditional operations. Earlier steno-occlusion of the popliteal artery was an indication for femoropopliteal bypass below the knee. Nowadays, endovascular procedures are also used, but the indication of the stent placement into the popliteal artery is controversial.

Aim: We have been using Jaguar stent for the treatment of popliteal artery steno-occlusion since January 2016. The aim of our study was to evaluate the efficacy of this treatment.

Method: We included patients who underwent popliteal artery angioplasty with Jaguar stent placement between 1 January 2016 and 31 December 2017 in our department. During the one-year follow-up, we examined the popliteal stent patency, amputation-free survival and risk factors that influence stent patency.

Statistical analysis: For the comparison of mean values, two-sided t-tests were used. Categorical data were analyzed by using chi-square test. 
Results: 33 patients underwent popliteal or femoropopliteal endovascular intervention with Jaguar stent placement into the popliteal artery. Postoperative complications that required surgical treatment occurred in 2 patients. At the end of the follow-up, the primary patency of the popliteal stents was $58.1 \%$, the secondary patency was $74.2 \%$ and amputation-free survival was $96.8 \%$.

Conclusion: Compared with international data, the primary patency of the Jaguar stents in our study is relatively lower, but amputation-free survival is much better, and in most cases there is less operative strain compared with traditional operations.

Keywords: chronic limb-threatening ischaemia, endovascular treatment, self-expanding stent

Takács T, Mihalovits G, Váradi R, Palásthy Zs. [Early experience with self-expanding flexible stent for the treatment of atherosclerotic diseases in the popliteal artery]. Orv Hetil. 2020; 161(15): 588-593.

(Beérkezett: 2019. november 11.; elfogadva: 2019. december 17.)

\section{Rövidítések}

a. $=$ arteria; $\mathrm{BKI}=$ boka-kar index; CLTI $=$ (chronic limbthreatening ischaemia) kritikus végtagischaemia; $\mathrm{CT}=(\mathrm{com}-$ puted tomography) számítógépes tomográfia; LEAD $=($ lowerextremity arterial disease) alsó végtagi érbetegség; LMWH = (low-molecular-weight heparin) kis molekulasúlyú heparin; $\mathrm{PAD}=$ (peripheral arterial disease $)$ perifériás érbetegség; SZTE $=$ Szegedi Tudományegyetem

Magyarországon a szív- és érrendszeri betegségek jelentik a vezető halálokot [1]. Emellett sajnálatos módon az európai átlaghoz mérve kiemelkedően magas a hazai amputációs ráta is [2]. A generalizált atherosclerosisnak érsebészi szemmel nézve az egyik legfontosabb formája a perifériás érbetegség (peripheral arterial disease - PAD), melyen szúkebb értelemben az alsó végtagi érszúkületet értjük (lower-extremity arterial disease - LEAD). Az alsó végtagi érszúkület jó specificitással és szenzitivitással szürhető kézi Doppler-vizsgálattal - a boka-kar index (BKI) mérésével -, ezáltal már korai stádiumban diagnosztizálható, és az esetek túlnyomó többségében mútéti beavatkozás nélkül is eredményesen kezelhető $[3,4]$. Bár az utóbbi években a hazai érgyógyász-társadalom szervezett szürőprogramokkal igyekszik elérni a betegség korai stádiumban történő felismerését, sajnálatos módon mégsem csökken a kritikus végtagischaemiák (chronic limb-threatening ischaemia - CLTI) száma sem. Ezen utóbbi esetekben sürgős, végtagmentő beavatkozások válnak szükségessé.

$\mathrm{Az}$ érrekonstrukciós eljárások jelentős változásokon mentek keresztül, melyek kezdetét a Dotter és mtsai által 1964-ben elvégzett első perifériás ballonos angioplasztika jelentette [5]. Bár a perifériás intervenciók száma az utóbbi évtizedekben már erőteljes növekedést mutatott, a hagyományos érmütétek sem tűntek el. A femoropoplitealis régió érbetegségeinek kezelésére korábban az érelváltozások morfológiája alapján tettek javaslatot az irányelvek, azonban az Európai Érsebészeti Társaság 2017-ben kiadott, a perifériás érszúkületek kezelésére vonatkozó ajánlásában már csak a kiterjedt $(>25 \mathrm{~cm})$ fe- moropoplitealis elzáródások esetén javasolja bypassműtét végzését [6-9]. Az irányelvek azonban nem tesznek különbséget az arteria femoralis és az arteria poplitea szegment között, már ami a kezelési stratégiát illeti ezeket együttesen mint femoropoplitealis régiót kezelik. Habár az irodalom az a. popliteát a femoralis érrel kombinálja, van köztük néhány különbség: a popliteaszegment nem izomkompartmentben fut, és ki van téve a térdmozgásokból származó flexiós-torziós mozgásoknak $[10,11]$. Az a. poplitea optimális kezelésére kevés adat áll rendelkezésre. Az intervenciók elterjedését megelőzően az a. poplitea szúkülete vagy elzáródása egy térd alá vezetett femoropoplitealis bypass mútéti indikációját jelentette. Manapság már az intervenciós módszerek is eredményesen alkalmazhatók ezen érszakasz kezelésében, nyilván válogatott esetekben, azonban a sztentek használatának indikációjában az irodalom nem egységes. Ennek legfontosabb magyarázata, hogy a térd mozgásából származó erők sztentbordatöréseket okozhatnak, melyek a sztent újraszúküléséhez vagy elzáródásához vezethetnek [12]. Ennek ellenére a poplitea-érszakasz kezelésében is használhatók sztentek, olyan típusúak, melyek nagy radiális erővel és jó flexibilitással rendelkeznek. Egyetemünk Érsebészeti Osztályán 2016. január óta használjuk a Jaguár öntáguló nitinolsztenteket az a. poplitea atheroscleroticus betegségeinek endovascularis kezelésében. Ezen időszak előtt is végeztünk a. poplitea intervenciókat, melyek azonban csak ballonos angioplasztikára korlátozódtak. Bizonyos esetekben (residualis szúkület vagy dissectio) a ballonos angioplasztika önmagában nem elegendő. Vizsgálatunk célja a Szegedi Tudományegyetem Sebészeti Klinikájának Érsebészeti Osztályán a Jaguár sztenttel végzett poplitea-intervenciós beavatkozások effektivitásának vizsgálata volt.

\section{Módszer}

Retrospektív tanulmányunkba a SZTE Sebészeti Klinikájának Érsebészeti Osztályán 2016. január 1. és 2017. december 31. között végzett perifériás endovascularis beavatkozáson átesett betegeket válogattuk be, akiknél 
az a. poplitea szegmentbe Jaguár öntáguló nitinolsztent beültetése is történt. A beavatkozás elött minden betegnél történt diagnosztikus hagyományos vagy CT-angiográfia. Rögzítettük a betegek életkorát, rizikófaktorait (kísérő betegségek, mint az ischaemiás szívbetegség, krónikus tüdő-, vesebetegségek - krónikus veseelégtelenség jelenléte -, magas vérnyomás, cukorbetegség, emelkedett koleszterin-, illetve trigliceridszint, a kor és a dohányzás mint fó rizikófaktor jelenléte). Az indikáció tekintetében a beavatkozásokat claudicatio vagy CLTI miatt végeztük; az előbbi csoportba a Fontaine II.B, míg az utóbbiba a Fontaine III-IV. stádiumú érbetegek tartoztak. Rögzítettük a kifolyópályák állapotát, az azonos oldali korábbi femoropoplitealis rekonstrukciók elvégzését, illetve a popliteasztentelés mellett az a. femoralison szimultán végzett beavatkozásokat (a. femoralis thrombectomia, endarterectomia vagy sztentelés). Ezen kombinált beavatkozásokat hibrid mütétek formájában végeztük, egyebekben az intervenciók percutan módon vagy ennek sikertelensége esetén (például a beteg alkata, anatómiai okok, súlyos meszes arteria a punkciós helyen) kis femoralis feltárásból direkt arteriapunkcióval történtek. Az a. popliteába sztentbeültetést azon esetekben végeztünk, amikor a ballonos angioplasztikát követően residualis szükület maradt vissza vagy dissectio alakult ki, valamint bizonyos hibrid beavatkozások során (például anterograd a. femoralis endarterectomiát követően a distalis intimalépcső fixálása céljából). Vizsgáltuk továbbá, hogy mely faktorok befolyásolják a sztentelt a. poplitea elzáródását. A betegeknél egyéves utánkövetést végeztünk. Az utánkövetési időszak végének 2019. január 1-jét jelöltük meg. Primer átjárhatóságként definiáltuk, ha az utolsó érsebészeti kontrollvizsgálaton a sztentelt popliteaér-szakasz jó átjárhatósága igazolódott fizikális (pulzusstatus, BKI) vagy képalkotó vizsgálattal (ultrahang, CT vagy hagyományos angiográfia), és egyéb érsebészeti beavatkozás ebben a régióban nem történt. Szekunder átjárhatóságként definiáltuk, ha a betegnél a sztentelt popliteaszegmenten reoperáció és/vagy reintervenció történt, és ezt követően az utolsó kontroll érsebészeti vizsgálaton az a. poplitea jó átjárhatósága igazolódott fizikális (pulzusstatus, BKI) vagy képalkotó vizsgálattal (ultrahang, CT vagy hagyományos angiográfia). Diabeteses betegeinknél, amennyiben a mútét előtti, illetve utáni BKI nem volt informatív, valamint az angiográfiás képeken súlyosan meszes cruralis érrendszer volt látható, az utánkövetést arteriás duplex ultrahangvizsgálattal végeztük, egyéb esetekben a rutinszerü kontrollvizsgálatokon BKI-mérés történt. Amputációmentes túlélőként definiáltuk azon betegeket, akik a vizsgált időszak végéig elkerülték a major amputációt, attól függetlenül, hogy reoperáción estek-e át, vagy csak konzervatív terápiát folytattunk a sztentelt a. poplitea elzáródása után. A popliteasztentek beültetése során a jó morfológiai eredményen túl azt is szem előtt tartottuk, hogy amennyiben esetleges reoperációra lenne szükség, alternatív megoldásként egy térd alá vezetett femoropoplite- alis bypass is technikailag kivitelezhető legyen. Betegeinknél a beavatkozást követően kettős thrombocytaaggregáció-gátló terápiát alkalmaztunk egy éven át, valamint a beavatkozás típusától, a beteg állapotától, illetve kísérô betegségeitôl is függően legfeljebb 30 napig LMWH-thrombosisprofilaxist is. A kettős thrombocytaaggregáció-gátló terápia részét képezte az aszpirin és a klopidogrél együttes adása a beavatkozást követően legalább egy hónapon át; ezt követően az egyiket cilostazolra cseréltük le, amennyiben ennek kontraindikációja nem volt, vagy szedésekor mellékhatás nem jelentkezett.

Statisztikai elemzéseink során a folyamatos változók összehasonlítását Student-féle t-teszttel, míg a kategorikus változók összehasonlítását khi-négyzet-próbával végeztük. Statisztikailag szignifikáns különbségnek a $\mathrm{p}<0,05$ értéket tekintettük.

Vizsgálatunkat a személyes adatok védelméról és a közérdekű adatok nyilvánosságáról szóló hatályos törvények figyelembevételével a Szegedi Tudományegyetem Etikai Bizottsága által rendelkezésünkre bocsátott, 122/2018. számú etikai engedély birtokában végeztük el.

\section{Eredmények}

2016. január 1. és 2017. december 31. között a SZTE Sebészeti Klinikájának Érsebészeti Osztályán összesen 33 olyan perifériás endovascularis beavatkozást végeztünk, melynek során a. poplitea intervenció történt Jaguár sztent beültetésével. A kezelt betegek rizikófaktorai az 1. táblázatban láthatók.

Az indikáció tekintetében 17 esetben $(51,5 \%)$ végeztük a beavatkozást claudicatio, illetve 16 esetben $(48,5 \%)$ CLTI miatt. 6 esetben $(6 / 33-18,2 \%)$ történt betegeinknél korábban azonos oldali femoropoplitealis rekonstrukciós beavatkozás, míg szimultán az a. femoralison 12 esetben $(12 / 33$ - 36,4\%) történt kiegészítő beavatkozás a beáramlás javítására. A kiáramlási pályát tekintve csak a betegek több mint felében volt nyitott mindhárom cruralis ér, itt is jelezvén, hogy jelentős részben emeletes - több anatómiai régiót érintő - érbetegségról van szó (2. táblázat).

1. táblázat | Rizikófaktorok az arteria poplitea sztentelt betegekben

\begin{tabular}{lcc}
\hline Rizikófaktorok & $\mathrm{n}=33$ & Arány $(\%)$ \\
\hline Ischaemiás szívbetegség & 10 & 30,3 \\
\hline Krónikus légzőszervi betegségek & 5 & 15,2 \\
\hline Krónikus veseelégtelenség & 4 & 12,1 \\
\hline Hypertonia & 29 & 87,9 \\
\hline Dohányzás & 28 & 84,8 \\
\hline Diabetes & 18 & 54,5 \\
\hline Hyperlipidaemia & 10 & 30,3 \\
\hline Kor (év) (átlag \pm szórás) & \multicolumn{2}{c}{$66,9 \pm 10,3$} \\
\hline
\end{tabular}


2. táblázat | A kifolyópályák állapota az arteria poplitea sztentelt betegekben

\begin{tabular}{lcc}
\hline A cruralis erek állapota & $\mathrm{n}=33$ & $\%$ \\
\hline 1 ér nyitott & 5 & 15,2 \\
\hline 2 ér nyitott & 9 & 27,3 \\
\hline 3 ér nyitott & 18 & 54,5 \\
\hline n. a. & 1 & 3,0 \\
\hline
\end{tabular}

n. a. = nincs adat

3. táblázat |Faktorok, amelyek befolyásolhatják a popliteasztent elzáródását

\begin{tabular}{|c|c|c|c|c|c|}
\hline & $\begin{array}{c}\text { Primer } \\
\text { sztent- } \\
\text { átjárhatóság } \\
(\mathrm{n}=18)\end{array}$ & $\begin{array}{l}\text { Arány } \\
(\%)\end{array}$ & $\begin{array}{c}\text { Elzáródott } \\
\text { sztent } \\
(\mathrm{n}=13)\end{array}$ & $\begin{array}{l}\text { Arány } \\
(\%)\end{array}$ & p-érték \\
\hline $\begin{array}{l}\text { Ischaemiás } \\
\text { szívbetegség }\end{array}$ & 7 & 38,9 & 3 & 23,1 & 0,352 \\
\hline $\begin{array}{l}\text { Krónikus } \\
\text { tüdőbetegség }\end{array}$ & 3 & 16,7 & 2 & 15,4 & 0,924 \\
\hline $\begin{array}{l}\text { Krónikus } \\
\text { veseelégtelenség }\end{array}$ & 4 & 22,2 & 0 & 0 & 0,069 \\
\hline Hypertonia & 17 & 94,4 & 11 & 84,6 & 0,361 \\
\hline Dohányzás & 13 & 72,2 & 13 & 100 & 0,038 \\
\hline Diabetes & 9 & 50 & 8 & 61,5 & 0,524 \\
\hline Hyperlipidaemia & 6 & 33,3 & 4 & 30,8 & 0,88 \\
\hline Kor & $68,0 \pm 11,2$ & & $62,7 \pm 8,6$ & & 0,147 \\
\hline Korábbi műtét & 3 & 16,7 & 3 & 23,1 & 0,656 \\
\hline $\begin{array}{l}\text { Beáramlásjavítás } \\
\text { (hibrid műtét) }\end{array}$ & 4 & 22,2 & 9 & 69,2 & 0,009 \\
\hline $\begin{array}{l}\text { Sztentátmérő } \\
(\mathrm{mm})\end{array}$ & $6,4 \pm 0,8$ & & $6,3 \pm 0,3$ & & 0,632 \\
\hline $\begin{array}{l}\text { Sztenthossz } \\
(\mathrm{mm})\end{array}$ & $81,2 \pm 13,2$ & & $83,0 \pm 12,4$ & & 0,701 \\
\hline \multicolumn{6}{|l|}{ Indikáció } \\
\hline CLTI & 7 & 38,9 & 7 & 53,8 & \\
\hline Claudicatio & 11 & 61,1 & 6 & 46,2 & 0,409 \\
\hline
\end{tabular}

CLTI = kritikus végtagischaemia

Reoperációt igénylő posztintervenciós szövődmény két esetben $(2 / 33-6,1 \%)$ fordult elö, az egyik esetben vérzés miatt, míg a másik esetben a sztentelt a. poplitea reocclusiója miatt; az utóbbi esetben femoropoplitealis bypassmútét vált szükségessé.

A beavatkozást követő első év végén a sztentek primer átjárhatósága $58,1 \%$ volt. A szekunder átjárhatóságot vizsgálva az eredmények már jobbak, az év végén ez $74,2 \%$ volt, míg az amputációmentes túlélést vizsgálva az eredmények rendkívül jónak mondhatók: az első év végén 96,8\%-os volt (1-3. ábra).

A popliteasztent elzáródása miatt az egy év alatt összesen 5 esetben $(5 / 31-16,1 \%)$ vált szükségessé térd alá vezetett femoropoplitealis bypass végzése. Az utánköve- tési időszakban két beteg exitált, egyéb kardiális okok miatt.

Azon faktorok vizsgálata során, amelyek befolyásolhatják a sztentelzáródást, pozitív korrelációt találtunk a dohányzás jelenléte és az egyidejűleg az a. femoralist (beáramlást javító) is érintő beavatkozás esetén (3. táblázat). Ez utóbbi beavatkozásokat hibrid mútétek formájában végeztük. Az egyéves utánkövetés során alkalmazott kettős thrombocytaaggregáció-gátló kezelés, valamint a posztoperatív 30 napig tartó LMWH-thrombosisprofilaxis időtartama során vérzéses szövődmény egyik betegnél sem történt.

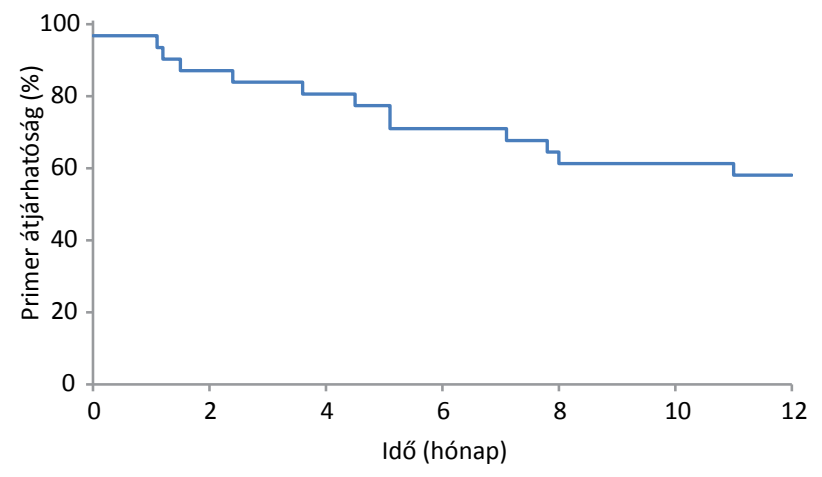

\begin{tabular}{l|l} 
1. ábra & $\begin{array}{l}\text { A Jaguár sztentek elsődleges (primer) átjárhatósága a vizsgált } \\
\text { időszakban }\end{array}$
\end{tabular}

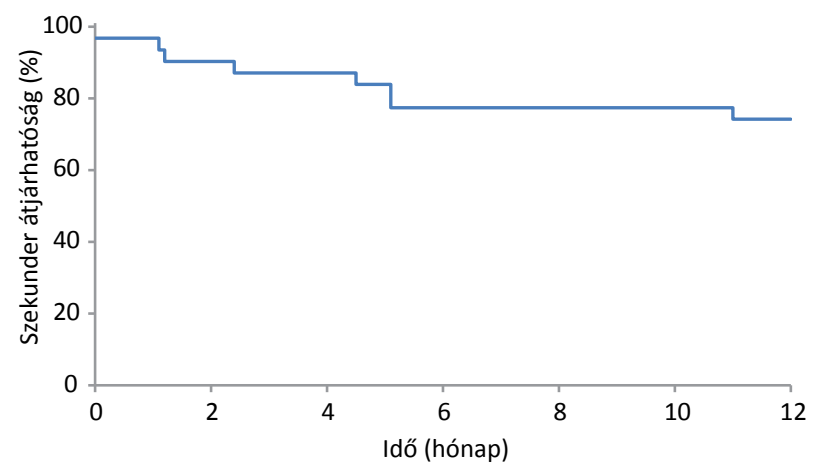

2. ábra $\quad$ A Jaguár sztentek másodlagos (szekunder) átjárhatósága a vizs gált időszakban

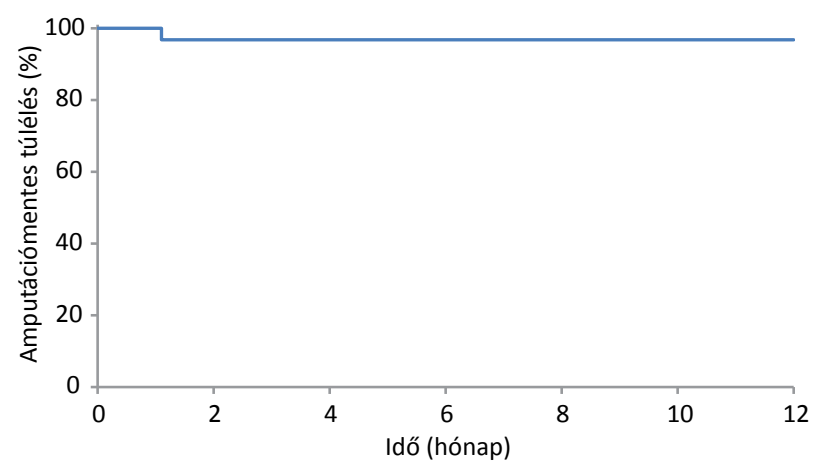

3. ábra $\mid$ A Jaguár sztenttel kezelt betegek amputációmentes túlélése a vizsgált időszakban 


\section{Megbeszélés}

A perifériás intervenciók száma az utóbbi időben növekszik, háttérbe szorítva ezzel a korábbi nyitott érsebészeti mútéteket. A fejlett nyugati országokban ez a tendencia még jelentősebb. Az endovascularis beavatkozásokat klinikánkon is egyre nagyobb arányban végezzük érsebészeti mütőben, sokszor hibrid beavatkozások keretei között, mely tendencia különösen a femoropoplitealis lokalizációjú érbetegségek kezelése során érezhető. Az a. poplitea szúküuletek kezelésében a sztentek használatának indikációjában az irodalom nem egységes az itt ható nyíró- és hajlítóerők jelenléte miatt, melyek a sztenteken bordatöréseket, újraszúkülést vagy elzáródást okozhatnak. Ennek az érszakasznak a kezelésére ezért a nagy radiális erővel és jó flexibilitással rendelkező öntáguló sztentek használhatók.

Egyetemünk Érsebészeti Osztályán 2016. január óta használjuk a Jaguár öntáguló nitinolsztenteket az a. poplitea atheroscleroticus betegségeinek endovascularis kezelésében. Ezen betegeinkben a Jaguár sztentek elsődleges átjárhatósága az első év végén $58,1 \%$-os, szekunder átjárhatósága 74,2\%-os, míg az amputációmentes túlélés már lényegesen jobb, 96,8\% volt.

Kevés nemzetközi tanulmányt publikáltak az a. poplitea atheroscleroticus betegségeinek kezelésére használt sztentek klinikai vizsgálatáról, s ezen vizsgálatok többsége is inkább nem randomizált, retrospektív jellegü volt. Potoczny és mtsai a miénkhez hasonló vizsgálatuk eredményeit 2018-ban közölték; 5 év alatt 172 betegnél végeztek Jaguár sztenttel a. poplitea intervenciót, melyet követően az első év végén a sztentek átjárhatósága 67\%os volt [13]. Scheinert és mtsai a hasonló tulajdonságú Supera öntáguló nitinolsztentet használták az a. poplitea intervenciók során 101 betegnél primer átjárhatósága az év végén $87,7 \%$-os volt [14]. Ugyanez a munkacsoport ezt a sztenttípust már komplex femoropoplitealis laesiók sztentelésére is használta, ezen esetekben 83,3\%-os sztentátjárhatóságot írtak le [15]. Az arizoniai León és $m t s a i$ által szintén Supera sztenttel kezelt izolált a. poplitea atheroscleroticus érbetegségek egyéves átjárhatóságának vizsgálata is hasonló eredményeket mutatott. Átlagosan 12,7 hónap utánkövetés mellett a primer átjárhatóság 79,2\%-os volt [16]. Kisebb beteganyaggal végeztek vizsgálatokat Chang és mtsai Dél-Koreában: ők csak 18 beteget vizsgáltak, akik a. poplitea sztentelésen estek át, azonban az átjárhatóság a 6 . hónapra itt csak $44 \%$-os volt - ezen eredményeiket a sztentbordatöréseknek tulajdonították [12]. Egy újabb, már heparinnal bevont nitinolsztentet (Tigris) használt a St. Thomas Kórház radiológiai és érsebészeti munkacsoportja a popliteaér-szegment kezelésében 54 betegnél. A 12 hónapos utánkövetés végén a primer átjárhatóság 69,5 $\pm 10,2 \%$, míg az amputációmentes túlélés $87 \pm 5 \%$ volt [17].

Az izolált a. poplitea atheroscleroticus betegségei ritkák, az esetek egy részében a femoralis régiót is belefoglalva vizsgálták azokat. Spiliopoulos és mtsai 4717 LEADesetet vizsgáltak meg, melyek közül csak 46 esetben igazolódott izolált a. poplitea érbetegség (0,98\%). Ered- ményeik alapján az a. poplitea ballonos angioplasztika és provizorikus sztentelés mellett az elsó évben $15,8 \%$ restenosis alakult ki, az esetek 90,5\%-ában azonban nem volt szükség reintervencióra [18]. A Rastan és mtsai által végzett prospektív randomizált tanulmány (ETAP study) is igazolta a popliteasztentek jobb nyitvamaradását a ballonos angioplasztikával szemben az egyéves nyitvamaradás tekintetében $(67,4 \%$ versus $44,9 \%$; $\mathrm{p}=0,002)$ [19].

Saját beteganyagunkat vizsgálva a rizikófaktorok tekintetében a dohányzás jelenléte, valamint egyidejűleg az a. femoralis kezelése a beáramlás javítása céljából szignifikánsan növelte a popliteasztent-reocclusiók gyakoriságát. Az előbbi eleve az atherosclerosis jól ismert rizikófaktora. Az Edinburgh-tanulmány szerint a claudicatio relatív rizikója 3,7-szeres a dohányosokban [20]. Az utóbbi is törvényszerûnek tûnik, mivel minél hosszabb érszakaszt kezelünk, annál nagyobb egy esetleges reocclusio gyakorisága [21]. A poplitea-intervención túl az a. femoralison végzett egyidejü beavatkozásokat hibrid mútétek részeként végeztük, így lényegében megállapítható, hogy a hibrid mütéteket követően nagyobb arányban történt popliteasztent-reocclusio.

Vizsgálatunk legfőbb limitáló tényezői a retrospektivitás, a relatíve alacsony esetszám, illetve az utánkövetés során a rutinszerűen nem végett röntgenkontroll voltak, ez utóbbi az esetleges sztentbordatörés vizsgálatára.

Az utánkövetés során fizikális vizsgálatot, kézi Doppler-vizsgálatot, BKI-mérést, valamint bizonyos esetekben (például diabeteses betegeinknél) arteriás duplex ultrahangvizsgálatot végeztünk. Amennyiben a vizsgálat felvetette a sztentelzáródás vagy újraszúküulés lehetőségét, és emellett a betegnek szubjektív panaszai is voltak, további diagnosztikus képalkotó vizsgálatokat készítettünk. Szubjektív panaszok hiánya esetén további invazív beavatkozásokat nem végeztünk; a terápiát alapvetően a beteg, illetve az alsó végtag állapota határozta meg. Az esetszám tekintetében a nemzetközi vizsgálatok is relatíve alacsony számú, csak az a. popliteára lokalizált atheroscleroticus beteget prezentáltak, ezek ugyanis általában a femoralis érbetegségekkel járnak együtt, és a kiterjedt femoropoplitealis érbetegségekre sokszor inkább a hagyományos érsebészi megoldásokat alkalmazzuk a klinikai gyakorlatban, ahogyan az aktuális Európai Érsebészeti Társaság legújabb irányelve is javasolja [8]. Válogatott esetekben hibrid mútétek formájában is kezelhetünk hosszabb szakaszú femoropoplitealis érelváltozásokat, saját beteganyagunkat vizsgálva azonban azok nyitvamaradásának aránya alacsonyabb, de végtagmentő indikációval mindenképpen használhatók, különösen olyan esetben, ha a betegnél bármilyen ok miatt bypassmütét nem végezhető.

Nemzetközi, illetve saját eredményeink alapján megállapítható, hogy a Jaguár sztentek alkalmazása hatékony és biztonságos a poplitea atheroscleroticus érbetegségeinek kezelésére; a sztent átjárhatóságának szempontjából ezen eredmények inkább az izolált a. poplitea érbetegségek (percutan végzett beavatkozások) esetén jobbak, az 
amputációmentes túlélés azonban mindenképpen jónak mondható, függetlenül az emeletes érbetegség jelenlététől.

$\mathrm{Az}$ a. poplitea intervenciókat egyetemünkön alapvetően érsebészeti mütőben végezzük, ami azért is előnyös, mivel az esetek jelentős részében több anatómiai régiót érintő érbetegségről van szó, melyeket egy ülésben tudunk kezelni. Ez a fejlődési irány még nem mondható általánosnak a magyar érsebész-társadalomban.

A jövőben intézetünkben továbbra is végzünk a. poplitea sztenteléseket, melyek során más eszközök, illetve sztentek is bevezetésre fognak kerülni; ezen eszközök hatékonyságának összehasonlítását is tervezzük vizsgálni, emellett a beteganyag bővítésével az utánkövetést tovább folytatjuk, hosszabb távú eredmények vizsgálata céljából.

Anyagi támogatás: A közlemény megírása, illetve a kutatómunka anyagi támogatásban nem részesült.

Szerzôi munkamegosztás: T. T.: Adatgyüjtés, statisztikai elemzés, irodalomkutatás. P. Zs.: Szakmai vezető, adatellenőrzés, javítási javaslatok. M. G., V. R.: Adatellenőrzés és irodalmi háttérkutatás. A cikk végleges változatát valamennyi szerző elolvasta és jóváhagyta.

\section{Érdekeltségek: A szerzőknek nincsenek érdekeltségeik.}

\section{Irodalom}

[1] Hungarian Central Statistical Office. Changes in the structure of causes of death in Hungary, 2000-2012. [Központi Statisztikai Hivatal. A haláloki struktúra változása Magyarországon, 20002012.] Available from: https://www.ksh.hu/docs/hun/xftp/ idoszaki/pdf/halalokistruk.pdf [accessed: November 11, 2019]. [Hungarian]

[2] Kolossváry E, Ferenci T, Kováts T, et al. Trends in major lower limb amputation related to peripheral arterial disease in Hungary: a nationwide study (2004-2012). Eur J Vasc Endovasc Surg. 2015; 50: 78-85. [Published correction appears in Eur J Vasc Endovasc Surg. 2019; 58: 783.]

[3] Aboyans V, Criqui, MH, Abraham P, et al. Measurement and interpretation of the ankle-brachial index, a scientific statement from the American Heart Association. Circulation 2012; 126 2890-2909. [Published correction appears in Circulation 2013; 127: e264.]

[4] Farkas K, Járai Z, Kolossváry E. Cilostazol is effective and safe option for the treatment of intermittent claudication. Results of the NOCLAUD study. [A cilostazol hatékony és biztonságos lehetőség a claudicatio intermittens kezelésére. A NOCLAUD vizsgálat eredményei.] Orv Hetil. 2017; 158: 123-128. [Hungarian]

[5] Dotter CT, Judkins MP. Transluminal treatment of arteriosclerotic obstruction. Description of a new technic and a preliminary report of its application. Circulation 1964; 30: 654-670.

[6] Norgren L, Hiatt WR, Dormandy JA, et al. Inter-society consensus for the management of peripheral arterial disease (TASC II). J Vasc Surg. 2007; 45(Suppl): S5-S67.

[7] European Stroke Organisation, Tendera M, Aboyans V, Bartelink $\mathrm{ME}$, et al. ESC Guidelines on the diagnosis and treatment of peripheral artery diseases: Document covering atherosclerotic disease of extracranial carotid and vertebral, mesenteric, renal, upper and lower extremity arteries. The Task Force on the Diagnosis and Treatment of Peripheral Artery Diseases of the European Society of Cardiology (ESC). Eur Heart J. 2011; 32: 2851-2906.

[8] Aboyans V, Ricco JB, Bartelink ME, et al. 2017 ESC Guidelines on the Diagnosis and Treatment of Peripheral Arterial Diseases, in collaboration with the European Society for Vascular Surgery (ESVS): Document covering atherosclerotic disease of extracranial carotid and vertebral, mesenteric, renal, upper and lower extremity arteries. Endorsed by: the European Stroke Organization (ESO). The Task Force for the Diagnosis and Treatment of Peripheral Arterial Diseases of the European Society of Cardiology (ESC) and of the European Society for Vascular Surgery (ESVS). Eur Heart J. 2018; 39: 763-816.

[9] Farkas K, Mátyás L, Palásthy Zs, et al. Professional guideline of the Hungarian Ministry of Human Capacities for the treatment of peripheral arterial diseases. [Az Emberi Erőforrások Minisztériuma szakmai irányelve a perifériás verőér megbetegedések ellátásáról.] Egészségügyi Közlöny 2017; LXVI(3): 650-675. [Hungarian]

[10] Kröger K, Santosa F, Goyen M. Biomechanical incompatibility of popliteal stent placement. J Endovasc Ther. 2004; 11: 686-694.

[11] Hoffmann U, Vetter J, Rainoni L, et al. Popliteal artery compression and force of active plantar flexion in young healthy volunteers. J Vasc Surg. 1997; 26: 281-287.

[12] Chang IS, Chee HK, Park SW, et al. The primary patency and fracture rates of self-expandable nitinol stents placed in the popliteal arteries, especially in the P2 and P3 segments, in Korean patients. Korean J Radiol. 2011; 12: 203-209.

[13] Potoczny PW, Janik P, Uryniak A. Angioplasty of the popliteal artery using the Jaguar ${ }^{\mathrm{TM}}$ stent. Acta Angiol. 2018; 24: 80-85.

[14] Scheinert D, Werner M, Scheinert S, et al. Treatment of complex atherosclerotic popliteal artery disease with a new self-expanding interwoven nitinol stent: 12-month results of the Leipzig SUPERA popliteal artery stent registry. JACC Cardiovasc Interv. 2013; 6: 65-71.

[15] Werner M, Paetzold A, Banning-Eichenseer U, et al. Treatment of complex atherosclerotic femoropopliteal artery disease with a self-expanding interwoven nitinol stent: midterm results from the Leipzig SUPERA 500 registry. EuroIntervention 2014; 10: 861-868.

[16] León LR Jr, Dieter RS, Gadd CL, et al. Preliminary results of the initial United States experience with the Supera woven nitinol stent in the popliteal artery. J Vasc Surg. 2013; 57: 1014-1022.

[17] Parthipun A, Diamantopoulos A, Kitrou P, et al. Use of a new hybrid heparin-bonded nitinol ring stent in the popliteal artery: procedural and mid-term clinical and anatomical outcomes. Cardiovasc Intervent Radiol. 2015; 38: 846-854.

[18] Spiliopoulos S, Kitrou P, Galanakis N. Incidence and endovascular treatment of isolated atherosclerotic popliteal artery disease: outcomes from the IPAD multicenter study. Cardiovasc Intervent Radiol. 2018; 41: 1481-1487.

[19] Rastan A, Krankenberg H, Baumgartner I, et al. Stent placement versus balloon angioplasty for the treatment of obstructive lesions of the popliteal artery: a prospective, multicenter, randomized trial. Circulation 2013; 127: 2535-2541.

[20] Fowkes FG, Housley E, Cawood EH, et al. Edinburgh Artery Study: prevalence of asymptomatic and symptomatic peripheral arterial disease in the general population. Int J Epidemiol. 1991; 20: 384-392.

[21] Banerjee S, Sarode K, Mohammad A, et al. Femoropopliteal artery stent thrombosis: report from the excellence in peripheral artery disease registry. Circ Cardiovasc Interv. 2016; 9: e002730.

(Takács Tibor dr., Szeged, Semmelweis u. 8., 6720 e-mail: drtakacs77@gmail.com) 